\title{
THOMAS BURN CATHERWOOD AND THE MEDICAL DEPARTMENT OF WELLINGTON'S ARMY: 1809-1814
}

by

KATE CROWE*

IN 1816, Thomas Burn Catherwood, a clerk who had served two years as a member of the supply and accounting branch of the army medical department, completed an account of his experiences during the late war. The manuscript of his Narrative of some of the transactions of the Purveyor's department which served with the Army in the Peninsula under the command of the Duke of Wellington. With anecdotes relating to the conduct of the medical department of that Army covers some 140 pages and was intended for publication; but for some unknown reason it never appeared in print, and even its existence was not generally known until it was catalogued as belonging to the Library of the Wellcome Institute for the History of Medicine. ${ }^{1}$

It is unlikely, however, that it would have attracted much attention had it been accessible earlier, for the honesty and efficiency of the officers concerned with hospital finance remained for many years one of the more recondite aspects of the Peninsular War, perhaps because so many official papers had been inadvertently destroyed in the 1840s. Even General Sir Neil Cantlie, in his recent history of the army medical department, treats the work of the purveyors briefly and with some confusion. Admitting first that their job "was not an easy one and the temptation of making money considerable", 2 he says that "it seems only too true that some feathered their own nests" ; but in a later chapter, although mentioning J. W. Fortescue's condemnation of the general hospitals as "hotbeds of waste and dishonest dealing", 4 he instances the director-general of the army medical department, Sir James McGrigor's inspection of those at Lisbon and Coimbra as evidence of order and regularity, and declares that "no major administrative scandals were ever brought to light, and the Commanderin-Chief on his visits never had adverse comments to make."5

It is Catherwood who sheds fresh light on the matter, for his long account had the specific object of unfolding "the grand mystery of the department; viz. the manner of plundering the soldier on the one hand and the public on the other, which is

*Miss Kate Crowe, B.A., Wellcome Research Fellow, Wellcome Institute for the History of Medicine, 183 Euston Road, London NW1 2BP.

I should like to acknowledge the generous support of the Wellcome Trust, which enabled me to undertake the research for this paper, and my thanks are also due to Mr. Brian Bond, Dr. Edwin Clarke and Mr. Evan Davies for reading and criticizing this paper in its earlier stages.

1 The Library of the Wellcome Institute for the History of Medicine: MS. No. 1529. I am grateful for permission to consult and quote from this manuscript.

2 Lt.Gen. Sir Neil Cantlie, A history of the Army Medical Department, Edinburgh and London, Churchill Livingstone, 1974, vol. 1, p. 295.

Ibid.

Ibid., p. 377.

$\checkmark$ Ibid. 


\section{T. B. Catherwood and the medical department of Wellington's army}

technically called in the department 'making money' or 'chiselling them'." ${ }^{6}$ It reads like a combination of sensational journalism and comic opera, written by a disappointed spinster, but if used with care, it can nonetheless be a source of useful information.

Catherwood, the son of a watchmaker in the East End of London, was appointed a purveyor's clerk in May 1812. He was sent immediately to Portugal, and worked there, in Spain, and in France, until the end of the war in 1814. During this period he was acting as an assistant to the purveyor-general, much of the time at headquarters, so he was in a position to know what was going on. He saw the embezzling which his colleagues were organizing, but he refused to take part in it, ${ }^{7}$ and his refusal, combined with a dour and self-righteous attitude, not unnaturally made him disliked. He had worked hard at his official duties and, at the end of the war, had hopes of promotion, which on demobilization would have entitled him to half-pay. But his superior officer deprived him of this privilege by submitting an unfavourable personal report, so that Catherwood's eventual attack was barbed as much by "resentment for the bad treatment . . . experienced" 8 as by feelings of duty. It must be admitted that he had an axe to grind, and that to prove his former colleagues' guilt so as to obtain the promotion he believed was his by right, he presents them in the worst possible light.

Another oddity is that Catherwood, ostensibly on the side of the angels, was very prejudiced against Wellington and McGrigor, so that one finds in his narrative an occasional and disconcerting championship of men whom he had earlier condemned. This prejudice would be incomprehensible but for the fact that if Catherwood disliked his colleagues, he was still intensely jealous of the status and privileges of his department: he exhibits to an almost pathological degree the traditional hostility felt by the civil for the military departments which bedevilled the army throughout the war. Another reason for Catherwood's hostility towards McGrigor lay in his belief that McGrigor had been trying to make him divulge information about the alleged frauds, without any real intention of repaying him with promotion. ${ }^{9}$

These considerations apart, it remains a fact that Catherwood's account stands up very well to examination. His dates and places are always correct; the monthly returns of the army show that he and the people he mentions were where he said they were stationed. Several unsavoury incidents involving purveyors do come to the surface in the McGrigor papers, and his comments on the character of certain medical men are independently corroborated by other writers-he describes a physician, Charles Tice, as having a quarrelsome nature, and this fits in with deputy-inspector of hospitals Thomas Thomson's allusions to Tice's "mean, selfish and irascible disposition". ${ }^{10}$ The overall circumstantial detail and scraps of reported conversation

- Catherwood, op. cit., note 1 above, p. 6.

${ }^{7}$ He may have been a Methodist: his family lived in Bunhill Row, a street which backed on to the City Road, where John Wesley had lived and built a famous chapel.

Catherwood, op. cit., note 1 above, p. 67.

- Ibid., p. 61. Sir James McGrigor (1771-1858). Inspector of hospitals under Wellington, 1812-1814. Appointed director-general of the army medical department, 13 June 1815.

${ }_{10}$ Wellcome Institute for the History of Medicine Library: MS. No. 4781. Thomas Thomson, Medical sketches, 1813-1815, p. 20. 


\section{Kate Crowe}

ring true, and it is undeniable that two of the chief purveyors, against whom Catherwood inveighed, were ignominiously dismissed from the service in 1822 , "having been guilty of fraudulent practices and gross misconduct in the Peninsula."11

In particulars too, Catherwood can be shown to be telling the truth, however incredible it may seem. He claimed first of all that the financial system was by its very nature open to abuse. The purveyors were responsible for supplying and maintaining the general hospitals of the army - they had to repair and keep the buildings used for this purpose clean, provide all food and drink, medicines, equipment and changes of linen, pay the wages of hospital servants and labourers, keep all accounts and provide necessary stationery.

Many supplies were sent from England, conveyed up-country by the commissariat, and delivered over to the purveyors in return for requisitions signed by senior officers, and receipts; but throughout the war, perishable goods such as foodstuffs, and urgently-needed replacements, as well as the cost of services, had to be bought or paid for in the country, and for this the purveyors naturally required ready money. This was obtained from two sources, known as the cash and the stoppage accounts. The first was fairly simple: the purveyor-general submitted an estimate of the expenses of the general hospitals for the coming month, and applied through the inspector of hospitals at headquarters to the military secretary for that sum. In 1812-1814 the monthly estimate was between $£ 20,000-£ 25,000$, and it was always forthcoming, as Wellington gave the hospitals financial priority.

The second source was rather more complicated. Each soldier had $6 d$. stopped from his pay each day in payment for his ration of food. When he was taken to a general hospital, however, $9 d$. was stopped from his pay to cover the cost of his food and that of medical comforts such as port wine, fresh fruit and milk. Clerks or servants went round the wards each day and took notes of the names and regiments of the patients, which information was transmitted to the regimental paymasters, checked against their own records of absences, and the amount owing to the medical department was thus calculated and credited to its account at the military chest. This was a paper transaction; pay was so much in arrears that the paymasters could do no more than inform the medical department that had the money been available, so much would have been to its credit; while the purveyors in turn spent up to the limit of the sum to which they were entitled, paid when they could, and asked their creditors to wait for the remainder. Minor assistants, such as washerwomen and labourers, were paid with the minimum of delay, but shopkeepers and merchants usually received something on account and were asked to wait, they being better able to extend credit. Each transaction had to be accounted for by bills and signed receipts, and these vouchers were periodically made up into returns, which had to be scrutinized by senior medical as well as purveying officers. But the unscrupulous could find an abundance of ways of nullifying these checks, and it might even be said that elaborations in the system merely acted as a spur to criminal ingenuity.

Each day an abstract was drawn up of the different foodstuffs required for the diets of the sick, and these formed the basis for the weekly and monthly returns.

${ }^{11}$ Sir Robert Drew (editor), Medical officers in the British Army, 1660-1960. vol. 1, 1660-1898, London, Wellcome Historical Medical Library, 1968, pp. 75, 129. 


\section{T. B. Catherwood and the medical department of Wellington's army}

But such abstracts needed no alteration to benefit the purveyors. They were in charge of the storekeepers whose duty was to issue food and extras such as lemons, sugar, etc., to the ward-masters, and by the use of false weights and measures, the patients could be fobbed off with smaller amounts than those actually prescribed by the doctors. Spirits could be watered and tea and sugar were often dampened to increase their weight. The difference was euphemistically termed a surplus, which the deputypurveyor could sell, either retaining the profit or sharing it with the storekeeper. The latter, remarked Catherwood, is "considered more or less fitted for his employment according to the quantity of surplus that he can create." 12

Perhaps Catherwood is exaggerating here to some extent. No doubt these minor frauds went on, but as they were more easily detected than other stratagems, they were a less attractive way of making money. As was remarked during the post-war investigations, "it was ever considered by the purveyors as a circumstance of consequence that no ground of complaint, either as to the quantity or quality of provisions should exist, as any reports of such a nature being made to the medical officers, must have led to investigations, which were ever studiously avoided."13

Nor was there any need for the purveyor to run such risks, for as Catherwood explained, they could make enormous profits with the minimum of effort when large quantities of goods were bought in the country. He said that it was customary for the officer in question to buy only what was required, but that he would persuade the merchant "to make a bill for the quantity for the employment of which he had obtained a voucher, and to annex a receipt for the value of those quantities, and thus he obtains a voucher for the payment of a larger quantity of money than he has really paid, and the value of the surplus provisions goes in the first instance into his pocket. These surplus provisions form the principal sources of the profits of a purveyor, and the amount not only would astonish one unacquainted with the department, but have more than once exercised the credulity of the chief of the department himself." 14 As long as the merchants received the money they had bargained for, claimed Catherwood, they would sign almost anything, and he cited one named Venancio who signed otherwise blank bills for the convenience of one of the purveyors.

Later investigations proved that Catherwood's accusations were founded in factindeed, that there were countless instances of such fraud. When asked if he was paid the exact amount of his account, a merchant of Abrantes replied that he was paid "exactly what was due to him, but that he received more money because the deputy purveyors inserted in his accounts larger quantities of articles, and some articles besides which he had not furnished, saying they had purchased this, and for this reason he returned them the difference between his account and those of the hospital."15 A clerk named Edward Fairman, when employed to detect frauds in the documents brought before the Audit Office, also declared that "the contractors were always ready to sign away papers put before them on the receipt of the amount of their respective Monthly Bills." 16

12 Catherwood, op. cit., note 1 above, p. 7.

18 Public Record Office/Audit Office/10/32/p. 227. E. J. Fairman to J. Mallet, 23 December 1818.

14 Catherwood, op. cit., note 1 above, p. 8.

${ }_{15}$ Public Record Office/Audit Office/14/32/pp. 13-14, 4 December 1818.

${ }^{16}$ Ibid., 10/32/p. 288. 


\section{Kate Crowe}

Another Portuguese, asked why he had signed as a witness to an account, although he had nothing to do with the man to whom the money was paid, declared that he had "signed without knowing what he signed, and it was well known to him that frequently papers were carried about to the coffee houses to be signed."17 Lewis Moreira, interrogated as to the name of a witness on his accounts, admitted that he thought he was "a man taken at random to sign . . . as was the customary practice."18 Most of the Portuguese submitted accounts in their own language, but signed accounts in English whenever requested to do so, and according to Manoel Dias of Coimbra, the former were destroyed as soon as they had been compared with the latter, and the English receipt signed. ${ }^{19}$

It was noticed in 1821 that "many persons swore that the signatures to receipts purporting to have been given by them were false, and that no such receipts ever had been signed by them." ${ }^{20}$ Francisco José Vieira, for example, when confronted with nine accounts accredited to him, acknowledged the signature to eight but declared the ninth false; and he disavowed having supplied such articles as wood, saying that "the purveyors sent for him to sign those accounts, and in truth he signed everything 'na boa fe!!' [in good faith]."21

Besides inflated and false accounts, the purveyors are shown to have evaded treasury regulations in other ways. Bills were supposed to be supported by a certificate from a man of good character, to the effect that the prices therein stated corresponded to the fair market price. But Antonio Cartacho, whose signature appeared on fifteen such certificates, told the auditor-general that "he signed everything without enquiry, being told that it was a form practised on such occasions." 22

When a new hospital was set up, the purveyor was charged with the job of making the available accommodation habitable. A surplus could be obtained from the cost of the materials, and the workmen could be tricked into signing lists which showed them to have worked longer than they actually had. The laundry lists could be falsified by inflating the number of items on the bills which would undergo scrutiny, and examination of various laundresses showed this to have taken place. Maria Clara and Maria Rita, both washerwomen who worked for the Estrela hospital in Lisbon, declared that they "never received anything like" 23 the sum which appeared on their accounts. Four bills for the year 1810 were for 547,670 reis $(£ 154), 68,450$ reis $(£ 19)$, $655,705$ reis ( $£ 184)$ and 269,105 reis $(£ 76),{ }^{24}$ whereas the women said that the largest sum paid to them was about 10 moedas $\left(£ 1310\right.$ s. $0 d$.). ${ }^{25}$ It turned out that they had only had charge of the linen for the last three years of the war, but that Maria Clara had signed receipts for washing for the whole period: she explained to the auditorgeneral that "they sent for her to the Estrela hospital and presented to her all the

${ }^{17}$ Ibid., 14/28/p. 6. Jozé de Sta. Rita Vieira, Lisbon, 7 November 1816.

18 Ibid., 14/27/p. 146. Lewis Moreira, 5 November 1816.

${ }^{19}$ Ibid., p. 60. Manoel Moreira Dias, Coimbra, 4 October 1816.

${ }^{20}$ Ibid., 10/33/p. 410. 15 November 1821.

21 Ibid., 14/27/p. 81. F. J. Vieira, Coimbra, 7 October 1816.

22 Ibid., A. J. Cartacho, 20 June 1816.

23 Ibid., 14/30/p. 143. 11 September 1817.

21 Ibid. 1000 reis (1 milreis) was worth about $5 s .7 \frac{1}{2} d .1$ dollar equals about 800 reis. The English equivalents of the sums quoted in reis are only approximate, having been taken to the nearest pound.

${ }^{25}$ Moeda as used here meant a gold coin-moeda de ouro-(Eng. Moidore) which was worth 27s. 


\section{T. B. Catherwood and the medical department of Wellington's army}

receipts for washing to sign, which she did na boa fé; so much so that on one occasion she remained a whole afternoon signing receipts, and when she had done, they gave her 800 reis" [4s. $6 d$.]. ${ }^{26}$

Catherwood said that it was especially easy to defraud the government over the wages of the hospital servants, for daily records were not kept of their employment - for the sake of neatness, one clerk was told to write up the accounts at the end of the month-making them up would have been the more accurate description of his work. The occasional false name was slipped in, but the usual ploy was to show them to have worked longer hours than was in fact the case. This job, remarked Catherwood, was often given "to the clerk employed in the victualling branch, as a reward for his fitness in that employment". ${ }^{27}$ Edward Fairman, who had taken an active part in defrauding the government, later admitted that he was well "aware of the frauds which took place in the Servants' Pay Lists." 28

The stationery accounts formed an irresistible source of outdoor relief for the undeserving poor, as requisitions were not checked until after supplies had been bought. The medical board in London was itself partly to blame, because its members refused to send out the amounts required. Britain was suffering from a serious paper shortage throughout the war, so that supplies were often hard to come by and very expensive. The board, in a misguided if understandable attempt at economy, restricted quotas to unrealistic levels, thereby "occasioning the purchase of large quantities at exorbitant prices abroad." ${ }^{29}$ Towards the end of the war, the stationery accounts had become so inflated that McGrigor put his foot down and refused to allow any more purchases of books and paper in the Peninsula at public expense.

The financial system of the general hospitals was obviously in need of reform, but its liability to abuse could have been surmounted if the officers engaged in its administration had been better supervised. It was expected that some would try to line their own pockets, but when two of the senior purveyors were themselves guilty of flagrant dishonesty, which Catherwood describes in great detail, they set the tone for the rest of their subordinates, who then knew that their activities would be condoned and even protected from investigation, lest embarrassing facts should be uncovered and prove the ruin of all.

Joseph Gunson was the head of the purveyor's department from 1808 until March $1812,,^{30}$ and Catherwood claimed that he had acquired a large fortune as a result of over three years' concentrated embezzling. He evidently believed that his pay was insufficient, for he applied for an extra allowance in 1810, but the members of the medical board replied that it was not possible. As they wrote, "we must lament that the arduous duties so meritoriously executed by that officer are thus inadequately rewarded. But the regulations of the treasury confine the pay of a purveyor to twenty shillings a day, and when anything beyond that rate ... has been granted, it was done

${ }^{26}$ Audit Office/14/30/p. 144 .

${ }^{27}$ Catherwood, op. cit., note 1 above, p. 9.

${ }^{28}$ Audit Office/10/32/p. 229.

29 Catherwood, op. cit., note 1 above, p. 9.

${ }^{20}$ See Drew, op. cit., note 11 above, p. 129, no. 1970. Gunson was appointed deputy-purveyor on 4 April 1800, purveyor on 16 February 1809 , and went on half-pay on 25 July 1814 . 


\section{Kate Crowe}

on the particular authority of the general commanding that station."31 When the army was so short of money, however, Wellington was unlikely to endorse Gunson's request for an increase in pay, so the idea was dropped in favour of unofficial ways of making money.

Much of Gunson's wealth resulted from his association with a Portuguese merchant called Lewis Moreira, whom he ordered to supply all the hospitals, whether in Lisbon or farther up-country. A witness examined at Abrantes said that "the intimacy was so great that it was generally repeated that they decided the profits between them, the purveyor blindly approved whatever Lewis Moreira determined,"32 and he even said that Moreira had once told him "that if he could not agree well with the purveyor in charge at Abrantes, to let him know and that he would have him sent away, as he had already done with two others." 33 Actual proof that Gunson was directly concerned in defrauding the government can be found in the testimony of Gregorio Simoens, a merchant's son, who was taken to the Estrela hospital "where were present two English officers whom he very well knew to be Messrs. Bacon and Gunson". ${ }^{34}$ He was presented with several receipts and asked to sign them, but when he demurred "by reason of his not knowing what they were [Moreira] told him to sign them as there was no danger whatever in so doing, which the said Bacon and Gunson likewise intimated by gestures, desiring him to sign the papers."35 Gunson also adjusted the stoppage accounts to his own benefit: it was calculated after the war that he had pocketed the money for 45,123 diets for fictitious patients in Lisbon alone. ${ }^{36}$ The average cost of each diet is unknown, but their number indicates the scale upon which his operations were conducted.

The total sum embezzled by Gunson is also unknown-the auditor-general spoke of "very large remittances ... to England . . . which were most satisfactorily brought home to him",37 and the commissioners for audit mentioned many thousands of pounds. An anonymous writer declared in 1850 that Gunson had amassed a fortune of $£ 65,000$, and although this cannot be confirmed it is certainly possible. ${ }^{38}$

According to Catherwood, Gunson was assisted by two clerks named Francis Bishop and Edward Fairman, who lost few chances of feathering their own nests. Bishop had been engaged in examining the provision accounts at Lisbon, but he was given leave of absence early in 1812 because Gunson was retiring (ostensibly from ill health) and needed someone to help with the task of arranging all his accounts for submission to the treasury. When Bishop returned to the army in 1813, however,

\footnotetext{
${ }^{31}$ Public Record Office/War Office/7/109/p. 24. John Weir (director-general of the army medical department) to Dr. James Franck (inspector of hospitals under Wellington, 1809-1811). 27 December 1810.

${ }^{32}$ Audit Office/14/28/p. 49. Manoel Nunes Carvalho, Abrantes, 24 December 1816. "Decided" could be a mistake for "divided".

s3 Ibid.

34 Ibid., 14/27/p. 35. Gregorio Simõens, Lisbon, 9 March 1815.

${ }^{85}$ Ibid.

${ }^{36}$ Ibid., 10/32/p. 295. Fairman to Commissioners of Audit, 9 March 1819.

${ }^{37}$ Ibid., 10/33/p. 410. 15 November 1821.

${ }^{38}$ Lancet, 1850, i: 733. Biography of G. J. Guthrie. This anonymous account contains some interesting information about peculation in the Peninsula, but there are many errors of detail. The explanation maybe that McGrigor or someone of equivalent seniority wrote it from memory and thus got some facts wrong.
} 


\section{T. B. Catherwood and the medical department of Wellington's army}

he took over the the accounts of the station at Vitoria and refused to share the profits with his colleague Copeland, saying "you will perhaps think it strange that during the last three months I have retained the whole of the surplus, but you should consider that for a long time I have been settling accounts in the rear, where I have had no opportunity of making anything." 39

Catherwood shows that a talent for conspicuous consumption was well developed in purveyor's clerk Fairman, describing him as "a man of most dissolute manners and the most profligate profusion; he played deeply, drank hardly (a bottle of champaign [sic] to tune his nerves before rising from bed) and he kept three girls, with all of whom he slept together."40 Fairman's morals were his own affair, but no harem could be run on a clerk's wages of five shillings a day, still less on extended credit, and it was the application of public money to private pleasure which made him an undesirable government servant. Nor was Catherwood exaggerating: the auditors admitted after the war that many objections could be made to Fairman's character, but that he was such a valuable source of information that his defects should be overlooked, and he was employed in their office to discover evidence of fraud in the purveyors' accounts. Fairman's only attractive feature was his handwriting.

Catherwood worked under George Dickson, ${ }^{41}$ Gunson's successor, so he gives much more detail as to his misconduct, and these accusations have also been substantiated by independent authorities. Appointed in January 1812, Dickson was apparently chosen to put a stop to the fraud which was suspected but never actually proved during the war. However, by the time he left in October 1813, he had not only carried on embezzling, but had adjusted the regulations so as to make it easier for himself and thus for his subordinates. The chief example of such manipulation can be seen in the matter of the sick maintenance accounts. Regulations stated that at the end of the month the principal medical officer of a hospital station would appoint a board of three medical officers whose duty it was to certify "it has examined the Return and compared it with the daily diet abstracts, and . . . it finds that the Diet and Extras therein stated to have been issued to the patients and servants in His Majesty's general hospital, conformably to the prescription of the attendant medical director." 42 Dickson had the words "and compared with the daily diet abstracts" struck out, by arguing that "while the return referred to other vouchers, it was not a complete voucher in itself, and that the Commissioners for Accounts might hereafter demand the daily abstracts which would cause inconvenience, on account of their number, and the slovenly manner in which they are written." 43 This was true, but it also meant that quantities could be inflated and written down in the return with much less chance of detection.

At Salamanca, Dickson was obliged to ask one of his clerks to check the surplus,

s9 Catherwood, op. cit., note 1 above, p. 45.

${ }^{10}$ Ibid., p. 18.

41 George Dickson-see Drew, op. cit., note 11 above, p. 75, no. 1217. Surgeon to the 12th Dragoons by purchase, 12 December 1793. Purveyor, 4 April 1800. M.D. St. Andrews, F.R.C.P. Edin. 1796.

18 Catherwood, op. cit., note 1 above, p. 17.

4 Ibid. 


\section{Kate Crowe}

remarking that "he had summed it himself, but doubted his accuracy because the amount of it was so considerable." ${ }_{44}$ Between September and October 1812, he had managed to create a profit of 22,000 dollars, the equivalent of $£ 6,93710 \mathrm{~s}$. $0 \mathrm{~d}$., and on top of this was the milk surplus: 540 pints had been consumed, but vouchers had been obtained for 15,650 pints, so that he pocketed another $£ 288 .{ }^{45} \mathrm{~A}$ similar situation occurred at Vizeu, under deputy-purveyor Smyth, and the board of general officers there not unnaturally felt that some of the quantities stated were excessive, and that the clerk had made a mistake. But Dickson forced them to sanction the return, shouting "what do you know of accounts? You have nothing to do but to sign your names. As for you, Mr. Power [the staff surgeon] you are drunk at the moment, and if you give me any more trouble I will put you in arrest."46

Dickson's avarice often led him to defraud his subordinates as well as the government; at Ciudad Rodrigo, for example, deputy-purveyor Findlay was ill, but when Dickson went to visit him, he took away all his papers and settled the account, keeping the surplus of 3,000 dollars ( $£ 675$ ) for himself. The clerks, for their part, resented the loss of their perquisites, and formulated ways of cheating Dickson to benefit themselves. Deputy-purveyor Copeland (apparently a relative of McGrigor) was peculiarly successful at this, and was reputed to pay his confidential clerks, Sherrin and Atkins, 400 dollars (£90) each a month.

Lest it seem that Catherwood was allowing his dislike for Dickson to colour his imagination, it should be remembered that the purveyor-general was found to have claimed stoppages for 146,657 fictitious patients at Lisbon alone; ${ }^{47}$ and that although he was in the Peninsula less time than Gunson, he is supposed to have acquired a private fortune of $£ 95,000.48$

When Dickson left in October 1813, he was succeeded by purveyor William James, who served in that capacity until the end of the war. Catherwood had a number of interesting things to say about James, of whom little information is otherwise known. McGrigor had the highest opinion of James, and declared that "a man of higher honour, more unspotted integrity, abler as an officer or more amiable in any quality as a man does not exist in any department of the army." 49 Catherwood admitted his amiability, but complained that he was not an efficient head of department. Dickson, for all his faults, had been an industrious man, and had kept his four clerks very busy, but James lacked decision and neglected his correspondence. As Catherwood recalled, "he appeared to dread the very sight of a paper, and it was with the greatest difficulty I could obtain his signature: frequently matters of some consequence were delayed for the want of it." 50 James also forgot to requisition account books for headquarters, and refused to sanction the purchase of any in the town, owing to McGrigor's recent prohibition of such expenditure. This was unfortunate, as the

4 Ibid., p. 10

45 Ibid., p. 13

46 Ibid., p. 15.

47 Audit Office/10/32/p. 295. Fairman to the Commissioners of Audit, 9 March 1819.

18 Lancet, op. cit., note 38 above.

4. McGrigor Papers, Peninsular Letter Book II, p. 401. McGrigor to Dickson, 16 December 1814. I am grateful for permission to quote from these papers, which are in the possession of the Aberdeen Medico-Chirurgical Society.

so Catherwood, op. cit., note 1 above, p. 39. 


\section{T. B. Catherwood and the medical department of Wellington's army}

clerks were unable "to keep the account of money advanced to the purveyor in proper form, and the greater part of the time which the army spent in winter quarters, so necessary for the arrangement of accounts, was absolutely lost. The quarterly return of stores of the 20 November 1813 was not made up until the 20 February 1814." 51 It was just as well that the war ended before the effects of the delay could be felt. James's alleged lack of administrative skill is borne out by post-war events: the medical board refused to sanction various sections of his accounts because they were not supported by the correct vouchers, and it was only with the help of McGrigor that their informality was finally rectified..$^{52}$

Catherwood's belief that James also encouraged dishonesty does not seem to have any basis in fact-it is far more likely that in his willingness to delegate he mistakenly gave too much responsibility to venal subordinates such as George Pratt. It should be pointed out in defence of James, that when McGrigor wrote his autobiography, after Gunson and Dickson had been dismissed, he saw no reason to change his view of James, but said that "although I believe nearly half a million pounds had passed through his hands, not a shilling of it stuck to them. So strictly honest was that gentleman, that with a large family, he found difficulty in living in London, and it took years of repeated applications through the Duke of Wellington to obtain the addition of four shillings to the half-pay which he could claim on retirement from the shortest service."53 And in all the investigations which the auditor-general carried out, no mention ever seems to have been made of James, and it seems most unlikely that anything suspicious in his behaviour would have escaped detection. Catherwood's accusations were probably derived from an unwillingness to extend the benefit of the doubt to one whom he thought had deprived him of promotion. James and Catherwood had not worked together easily-Catherwood had probably shown his contempt for James's lack of method rather too openly, whereas James must have found his clerk's air of overworked, martyred duty very irritating.

It will be asked what effect this systematic peculation had upon the army and the medical department in particular. It might seem at first glance that the sick did not suffer at all, for if what Fairman said was true, they were supplied efficiently because any lapse would have attracted attention, and might have led to an investigation. The purveyors made money less by depriving the sick than by overcharging the government. In another sense, however, it all came to the same thing, for the money appropriated by the purveyors could have been used to pay off bills outstanding, thus helping to restore the credit of the army in the Peninsula, and making it easier to obtain supplies later.

It might even be said that the sick did suffer as a result of Gunson's relationship with Moreira, for the latter was in such a strong position that he could have provided substandard goods without fear of reprimand or the termination of his contract. Manoel de Freitas claimed that delay occurred because Moreira sent goods from Lisbon which could have been obtained in Coimbra for the hospitals, and also that on arrival, these stores were found to be of poor quality. The disadvantage to the

61 Ibid., p. 40.

62 McGrigor Papers, op. cit., note 49 above, p. 404. McGrigor to James, 15 June 1815.

ss Sir James McGrigor, Autobiography and services, London, 1861, p. 360. 


\section{Kate Crowe}

sick of having to wait for shipments from the Tagus was obvious, but Freitas' second claim should be taken with a pinch of salt, as he had been cheated by Moreira, and was owed "more than 200 milreis" (over £56)..$^{54}$ It should also be remembered that such widespread corruption resulted in a strained atmosphere between the medical men and some of the purveyors: the former became suspicious of the latter, who in turn established themselves as a separate clique instead of being assimilated into the administrative team.

In view of such suspicions, it is remarkable that fraud was allowed to continue so long unchecked. When McGrigor came out to the Peninsula in January 1812, he had orders to investigate stories that there had been great waste and profusion in the purveyor's and apothecary's departments, ${ }^{55}$ and Wellington gave him some anonymous letters on the subject which had arrived a few weeks before. Even so, McGrigor could find nothing more than a tendency to extravagance, and the deterioration of goods kept in store too long. Towards the end of the war, however, he could not help being aware that the situation had grown worse: in a circular letter to the principal medical officers of hospital stations, he said "the accounts of the peculations committed in the general hospitals of this country have even reached England, and I have received several communications on the subject .... It is stated to me that at some hospital stations, robbery and peculation have become so familiar that the sense of the criminality of such conduct has been lost. . . . I cannot help thinking, ${ }^{56}$ he went on, that if the gentlemen of the purveyor's department discharged their duty more zealously, robbery and peculation from the stores could not take place." 57 This letter shows that although McGrigor recognized that something was wrong, he had no idea of how the fraud was being perpetrated-he was thinking of schemes to cheat the government of stores already bought and paid for, whereas the most money was being made from fictitious transactions carried out at purveyor and deputy-purveyor level.

Medical men who worked in closer contact with the purveyors, such as staffsurgeon (later deputy-inspector) G. J. Guthrie, had a better idea of what was going on, but they were themselves so busy that they had no time to investigate it. Paperwork already swallowed up too much time, they were always short of staff, and thus they could not afford to carry out the close scrutiny of accounts which was the only way to check fraud. Nor had they any real reason to interfere with the purveyors unless they failed in the essential duty of providing food and supplies for the sick-a rare occurrence. Neglect of that duty was immediately obvious and retribution correspondingly swift -at San Sebastian, for example, deputy-purveyor Hardy was placed under arrest and court-martialled for disobeying orders and feeding the sick on salt meat and biscuit.

It should be emphasized that the venal purveyors were very clever in staving off investigation, and Catherwood explains Dickson's importance in this respect very clearly. He said that Dickson concealed his own dishonest activities by using subordinates such as George Pratt in "the secret arrangements of surplus affairs with

${ }^{54}$ Audit Office/14/27/p. 69. Coimbra, 5 October 1816.

${ }^{55}$ McGrigor, op. cit., note 53 above, p. 256.

so McGrigor Papers, op. cit., note 49 above, p. 265. Circular Letter, St. Jean, 20 February. 1814. ${ }^{67}$ Ibid. 


\section{T. B. Catherwood and the medical department of Wellington's army}

deputies in charge of hospital stations ... when apprehensive of committing himself by too much personal interference." ${ }^{58}$ This was found by the commissioners to be true-the washerwoman Maria Rita, for example, said that it was Pratt who encouraged her to sign the fictitious receipts at Lisbon..$^{59}$

Nor did Dickson draw attention to himself by a display of wealth: Catherwood said he was thought to have sent $£ 10,000$ to England by means of bills purchased in Oporto by one of his clerks, and at the beginning of 1813 , to have deposited another $£ 5,000$ with a merchant in Lisbon. The commissioners were able to trace many such transactions back to Dickson, and they formed the chief evidence against him, as with no private income he could scarcely have accumulated such sums honestly. Catherwood also explains another factor which worked in Dickson's favour. He said that the department was given the job of paying the wages of the officers of the hospital staff of the army, and that although Dickson grumbled outwardly about the extra work this entailed, he was secretly delighted, as it would afford a plausible "explanation of an apparent advance of money from general hospital accounts, or of any remittances to England which might come to light." ${ }^{60}$ Evidence in the McGrigor papers shows that the purveyors were indeed requested to pay the general hospital staff, as well as the servants, owing to the difficulty and delay which had been experienced when orthodox paymasters had to travel round to the various stations. ${ }^{61}$

Dickson's ever-present concern to cover his tracks is well illustrated by this story from Catherwood: when the scarcity of money was at its height in 1813, Dickson had so much wealth that he was afraid that after his accounts with the treasury should be stated, it might be seen that he had spent more than he had received at the time. Thus, "in order to prevent the bad impression which such an appearance would make, he pretended to have borrowed a considerable sum from a commercial house in Lisbon, on his own personal credit and security, in order to employ it for the public service". ${ }^{22}$ Some of his deputies appear to have equalled his skill in dissimulation: Macpherson at Vera told the clerk with whom he shared his profits to ride over to headquarters, plead penury, and ask Hodges (one of the senior purveyors but an honest man) for "two weeks wages in advance-it would look well."63

To draw suspicion away from himself, Dickson frequently complained of the calibre of his subordinates in general, yet he never initiated proceedings against anyone. When an independent investigation threatened ruin, declared Catherwood, Dickson misused his position to rig the inquiry so that nothing embarrassing could be revealed. This was the case of Samuel Cooper, the deputy-purveyor at Coimbra, under whose auspices "peculation was carried out to its greatest extent; not only by the more usual means of producing a surplus of provisions, but by the more dangerous method of

${ }^{58}$ Catherwood, op. cit., note 1 above, p. 10. He said of Pratt, "during more than two years while he had been out there, he had never wanted money, but he had not drawn a penny from home. Yet Mr. Pratt always made a handsome demonstration, and was usually called Count Pratt by the canaille of the department."

${ }^{59}$ Audit Office/14/30/p. 144. 11 September 1817.

${ }^{\circ}$ Catherwood, op. cit., note 1 above, pp. 13-14.

61 McGrigor Papers, op. cit., note 49 above, Microfilm no. 6, p. 169 (in possession of the Royal Army Medical College Library, Millbank). McGrigor to Dickson, Castello Bom, 9 December 1812.

is Catherwood, op. cit., note 1 above, pp. 13-14.

63 Ibid., p. 42. 


\section{Kate Crowe}

altering figures in the daily diet abstracts, or prefixing new figures before computing the monthly returns of expenditure." ${ }^{\circ 4}$ The alterations were detected, and reported to Dr. Tice, the senior medical officer at the station, but he was unwilling to press the inquiry as he was in debt to Cooper, and was himself guilty of impropriety by accepting gifts of hospital stores from purveyor's clerk Fairman, for the use of his family. Fairman then tried to blackmail Cooper, and the result was deadlock, their knives in one another's backs like Tilburina and friends in The Critic. Tice finally held a committee of inquiry, but as he was very careful in his choice of witnesses, and Fairman chose to resign, nothing was disclosed. The unsatisfactory nature of the inquiry still managed to leak out, however, and a new court was ordered to assemble at Lisbon. The situation looked very black indeed for Dickson, as he was to be assisted in his investigations by staff-surgeon Hosack, who was noted for his integrity, and by deputy-inspector Guthrie, who "had upon several occasions demonstrated by his vigilance that he did not possess . . . feelings of friendship towards the purveyor's department." ${ }^{\text {65 }}$ A full investigation seemed inevitable, and by providing clues towards the system of peculation carried on elsewhere, Dickson's own ruin seemed only a matter of time.

Catherwood was ordered to take minutes of the court proceedings when it met in March 1813, but he stated that the whole concern suffered a severe setback when it was learned that Cooper had absconded. Against Dickson's advice, Guthrie asked the British Ambassador to organize a search for the missing defendant, but it was unsuccessful. All the court could do in his absence was to examine the accounts, and Dickson was able to show that the arithmetic was perfectly correct. The court subsequently decided that "there was no ground of suspicion against him, other than his having absented himself . . . and that even upon that score, some allowance should be made for the feelings of a timid man accused of so serious a crime." ${ }^{66}$ The latter observation was apparently inserted by Dickson despite the disapproval of Guthrie, to whom flight savoured far more of an admission of guilt. Cooper was thus merely superseded for having gone absent without leave, and he was said to have turned up in England in 1816, demanding the arrears of pay due up to the date of his supersession.

Fairman was then summoned to appear before the court, but his testimony was not enlightening; Catherwood heard that deputy-purveyors Pratt and Bishop had bribed Fairman with 3,000 dollars ( $£ 675$ ) of Dickson's money to blacken his own character, which he was willing to do now that he had left the service. He then pleaded ill health, and refused to attend any more, and the court, feeling that in any case little reliance could be placed on the word of so dissolute a man, terminated the proceedings. All that happened to Fairman was his incarceration for twenty days in Fort St. George, on Wellington's orders, and Dickson was safe once more.

Remarkable though this story seems, there is reason to believe it true in its essentials: a biography of Guthrie states that "during his stay in Lisbon, serious charges of peculation ... were brought under his notice ... which he was ordered to investi-

os Ibid., p. 19.

es Ibid., p. 20.

os Ibid., p. 23. 


\section{T. B. Catherwood and the medical department of Wellington's army}

gate", ${ }^{67}$ and on the 31 March 1813, McGrigor informed the medical board in London that "deputy purveyor Cooper against whom charges for peculation were adduced, has absented himself from this service without leave."

It might be said that McGrigor was at fault in being totally mistaken in his estimate of Dickson's character. Catherwood shows that Wellington had a poor opinion of Dickson, but McGrigor, although he "always knew that Dr. Dickson was a man of a bad temper and of a tyrannical disposition, yet . . . thought him an honest man", and defended him against Wellington's complaints. At Lesaca, for example, late in 1813 , the case of deputy-purveyor Hardy's neglect of duty was followed by the insubordination of deputy-purveyor Saunders, and these two incidents reinforced Wellington's belief that Dickson was unfitted for his situation: it seems that only the support of McGrigor prevented his dismissal. It was a pity, however, that McGrigor trusted Dickson, for the task of stamping out abuses was left to the initiative of the departmental head, who had no intention of doing any such thing.

On the other hand, Dickson projected a very clever simulation of honesty, which McGrigor could hardly have seen through when their acquaintance was an official relationship of letters, reports and occasional meetings. And as Dickson's demeanour satisfied McGrigor, it was natural to leave him to manage his department: interference would have savoured of lack of confidence, and in any case, McGrigor was far too busy, like the staff-surgeons at general hospital level, to duplicate the work that had been delegated to others. All he could do was to "mark strongly the conduct of undeserving officers"70 when they came his way. McGrigor defended Dickson because it was always his policy to give "uniform support" 11 to well-meaning subordinates, and he thought Dickson was doing this best under very unfavourable circumstances.

Catherwood's revelations are so detailed and comprehensive that it is natural to suppose that he was directly and chiefly responsible for the detection of Gunson's and Dickson's crimes. On closer examination, however, it is obvious that the part he played was relatively small. He first approached McGrigor in February 1816, and offered to disclose all he knew in return for promotion, but the auditor-general had already arrived in Portugal and had begun to examine the merchant Moreira and other witnesses in July 1815. These investigations revealed anomalies and sowed disquiet in the minds of the authorities quite independently of anything said by Catherwood.

It is interesting to note how the auditor-general was sent to Lisbon in the first place. C. M. Clode declared that when statutory power was conferred upon the comptrollers (a branch of the treasury) for the examination of army accounts, such savings were effected by them in military expenditure that the government decided to appoint a fourth comptroller "with a separate establishment to act with the Army abroad, and to exercise powers still more extensive than those which were entrusted to his

'7 Lancet, op. cit., note 38 above.

o8 McGrigor Papers, op. cit., note 49 above, p. 268. McGrigor to A.M.B., 31 March 1813.

80 Catherwood, op. cit., note 1 above, p. 61.

${ }^{70}$ McGrigor Papers, op. cit., note 49 above, p. 402 . McGrigor to Dickson. 16 December 1814.

${ }^{71}$ Ibid. 


\section{Kate Crowe}

colleagues at home."72 In consequence of this decision, Richard Dawkins was ordered "to proceed at once to Spain or Portugal, there to exercise his office under the direction and control of the Treasury, with authority to require all persons receiving money or public stores for which they were accountable, to render an account of the same on oath, and to exhibit all papers and vouchers necessary to substantiate the account." 73

It seems, however, that the credit for this innovation belongs to Wellington, for he wrote to Lord Bathurst on 13 April 1813 and suggested that "an auditor general of accounts should be attached to this army, with the power of calling upon all persons to whom public money may be entrusted, or to whose charge stores may be delivered either for issue or otherwise, to account for the same and to pass finally such accounts. The auditor general should have the means and power of inquiring into the prices of articles, and the conduct of persons entrusted with the expenditure of public money or the charge or issue of stores." ${ }^{44}$ It was also Wellington's idea that the auditorgeneral should reside at Lisbon for the final examination of the army accounts.

Wellington was inspired by various motives: he thought that the system whereby Sir Robert Hugh Kennedy, the commissary-general, was the only person accountable to the public was both unfair and unsatisfactory. The sums involved were so large that it took far too long to discharge them and give Kennedy his quietus, and it was unreasonable that he should be "responsible for the acts and conduct of his deputies, for their honesty and abilities and their fitness for their situations and duties, although they are appointed by other authorities over which the commissary general has no control." 75 Wellington wanted Kennedy to remain the head of finance with the army, but that his responsibility for money should cease with the production of a receipt from the officer to whom money was given for properly sanctioned purchase or expenditure, and such an officer should be responsible for the account of such expenditure and of rendering the account within a limited duration. This would cut down the period of waiting, and the control of the audit office over the accountants would be immediate and direct.

The treasury did not comply with all Wellington's requests, but it did appoint Richard Dawkins as auditor-general, and he arrived with a staff of fifteen to be noticed in General Orders on 14 November 1813. He established an office in the Rua do Collegio dos Nobres ${ }^{78}$ in Lisbon, where witnesses were examined under oath in the company of a Portuguese judge, a notary and the British Vice-Consul, ${ }^{77}$ and the proceedings written down, wherever necessary, in Portuguese and English. The same procedure was carried out when Dawkins pursued his researches in Coimbra, Abrantes, and other towns.

Dawkins had to examine the accounts of the commissariat as well as those of the purveyors, so it is not surprising that persons concerned with Gunson's and Dickson's

${ }^{72}$ C. M. Clode, The military forces of the Crown, London, 1869, p. 192.

7s Ibid.

74 The dispatches of Field Marshal the Duke of Wellington, vol. X, London, John Murray, 1838, p. 289. W. to Bathurst, 14 April 1813.

${ }^{75}$ Ibid., p. 288.

${ }^{76}$ Now the Rua da Escola Politécnica.

${ }^{7}$ Sebastião José Xavier Botelho, D. J. M. de Mendonça, George Hewson. 


\section{T. B. Catherwood and the medical department of Wellington's army}

accounts were not summoned until 1815. The examination of Moreira and tradesmen like Francisco Lourenço and Gregorio Simõens were sufficient, however, to show that little reliance could be placed upon the accounts and vouchers submitted by Gunson.

At the same time and for reasons best known to himself, Edward Fairman had written to the treasury, alleging that fraud had been committed by some of his former associates, and these letters were passed on to the comptrollers of army accounts in London on 25 and 30 January $1816 .^{78}$ The following March they were sent to Dawkins, and in June the treasury decided that Fairman would join him in Lisbon.

Thus when Catherwood offered to tell the authorities in London all he knew about irregularities in the Peninsula, he found them better informed than he expected. But the report that Dickson, as well as Gunson, was guilty of fraud was new to McGrigor, and he told Catherwood "if these things can be proved against him, notwithstanding our acquaintance, I shall not regret the most ignominious punishment that may be inflicted upon him." 79 Advising Catherwood that it was now more likely that promotion would be forthcoming, if he rendered "assistance in bringing these affairs to light", ${ }^{80}$ McGrigor then referred him to the treasury. Catherwood was informed late in July that year that he would be given every encouragement to reveal all he knew, and that any claims he felt entitled to make concerning compensation would receive due consideration. On 10 August 1816 he again requested promotion, and explained that the information he could give in exchange consisted of a description of the system of peculation practised within the department, and the relation of "some interesting circumstances which have come to my knowledge." ${ }^{81} \mathrm{He}$ also said that he was able to call "viva voce evidence to prove some particular acts of peculation, and to point out a method by which, I doubt not, numerous facts of a like nature would be brought to light." ${ }^{82}$ This letter was sent to Lisbon by the comptrollers, and it was March 1817 before Catherwood received a reply.

The comptrollers suggested that he take a temporary post in the audit office, where he would be employed in examining the accounts of the purveyors; with a salary of $£ 200$ per annum, a lump sum of $£ 100$, and the prospect of further advancement if he rendered "essential service to government". ${ }^{83}$ Catherwood still wanted promotion, however, and as he was about to take up a new post elsewhere, the audit office presented no charms to him. He thus refused the offer and the authorities considered the matter closed. Catherwood himself never seems to have raised the question again.

Catherwood therefore contributed little to the process of detection. The credit belongs mainly to Dawkins, for it was the examination of witnesses throughout Portugal during 1816 and 1817 which established the guilt of Gunson and Dickson. On 12 November 1817, the auditors informed the lords of the treasury that "state-

${ }^{78}$ Audit Office/17/138/p. 250. Comptrollers' Office, 24 June 1816. John Erskine and John King to the Lords Commissioners of the Treasury.

70 Catherwood, op. cit., note 1 above, p. 61.

${ }^{\text {so }}$ Ibid.

${ }^{81}$ Ibid., p. 75.

${ }^{82}$ Ibid.

${ }^{83}$ Public Record Office/Treasury/1/1616. Bundle 7558. Audit Office, 16 April 1817. Wm. Mackenzie Praed, C. W. Rouse Boughton, J. Whishaw to the lords of the treasury. 


\section{Kate Crowe}

ments of great malversation and fraud in the department of purveyor to the forces"84 had been obtained, and it was therefore desirable that proceedings against the two purveyors-general should proceed without delay, subject only to the advice of the treasury solicitor.

No such action was taken in 1818 , because Dawkins had sent Fairman home to compare the stoppage returns submitted by the purveyors with those from the various regiments. It was a long job which went on into 1819 , but it was rewarded by the discovery of enormous discrepancies. More would doubtless have been uncovered if it were not for the fact that some registers-such as those for Coimbra-were missing or incomplete.

In June 1820 the comptrollers were again ready to institute proceedings against the two purveyors, when a letter from Dawkins arrived, saying that further information might be obtained against them from a Scottish merchant called Shirreff. Another delay thus occurred while the fresh line of inquiry was being pursued. It was unsuccessful, but in the meantime Dawkins had sent home a clue to the money transmitted to England by Gunson and Dickson, and after the examination of several bankers and agents, "the immense extent of the remittances" 85 was established "beyond all doubt". ${ }^{86}$ Taken as a whole, remarked the comptrollers, the papers which they were submitting to the lords of the treasury "contain such evidence of the large fortunes realized by ... [Gunson and Dickson] without any other apparent means than that of frauds committed upon the public, and forming probably but a small portion of the real loss sustained by this misconduct"', 87 that it seemed neither right nor desirable that the purveyors "should escape with a simple dismissal, if any possible mode could be devised of bringing them to justice." 88

In October 1822, George Harrison, secretary to the lords of the treasury, requested the treasury solicitor to take the necessary steps for the immediate removal of Gunson and Dickson from the service, and, as both were residents of Scotland, he asked whether it might be "expedient to have an immediate communication with the lord advocate of Scotland . . . with a view both of rendering the Parties amenable to justice and to prevent the removal or concealment of any property of which these parties may be possessed in that part of the United Kingdom." 89 The solicitor worked quickly and on 15 November 1822 Gunson and Dickson were ignominiously dismissed.

It is not known whether civil or criminal proceedings were then begun against the purveyors, or whether any of the money was recovered-their lives after their dismissal remain a mystery. One comment, however, remains to be made-that it was not surprising that Sir Robert Hugh Kennedy underwent so much time and trouble trying to discharge his accounts: quite apart from the amount and complexity of

\footnotetext{
84 Audit Office/8/13/p. 337. 12 November 1817. Commissioners of Audit to the lords of the treasury.

${ }^{85}$ Audit Office/17/141/p. 350. Comptrollers' Office. 14 July 1821. John King and A. Rosenhagen to the lords of the treasury.

${ }^{86}$ Ibid.

${ }^{87}$ Ibid., p. 354.

88 Ibid.

${ }^{80}$ Treasury/15/3/p. 259. George Harrison to the Treasury Solicitor, 5 October 1822.
} 


\section{T. B. Catherwood and the medical department of Wellington's army}

the paperwork, the comptrollers, with Gunson and Dickson fresh in their minds, were doubly suspicious of any anomaly, and they had to be convinced that the commissarygeneral really was an honest man and not a swindler.

In the light of their previous depredations, it seems rather odd that subordinate officials such as Pratt and Bishop should retain their jobs. But if one considers just how honest these public officials were expected to be, the decision to make an example of the big fishes and to spare the small fry seems to be justice only slightly tempered with mercy. A comparison with the commissariat department is instructive, for the purveyors and the commissaries laboured under similar disadvantages. The life of a commissary was not an easy one, for work during a campaign was arduous, thankless, and considering its importance, relatively ill-paid. For a long time, therefore, it was "the last refuge of decayed merchants and rogues intent upon supplementing their official income from the disposal of public money and stores entrusted to them." S. G. P. Ward has said that "it was almost expected of a commissary that he would defraud the public"91 and this naturally encouraged a low standard of honesty. According to Wellington, "the prejudice of society against a commissary almost prevents him from receiving the common respect due to the character of a gentleman", ${ }^{22}$ so no wonder men of education and integrity were rarely willing to join this branch of the service. Colonel Willoughby Gordon and J. C. Herries tried to raise the standard of officers admitted to the commissariat by instituting entrance examinations in English and arithmetic, followed by personal interviews with the commissary-inchief, ${ }^{93}$ but the quality of the candidates who submitted themselves was so low, and the need of the army for staff so great that little discrimination could be exercised, and the situation was little better than before.

If this was true of the commissariat, it was even more true of the purveyor's department. During his term as surgeon-general, Thomas Keate had tried to improve the quality of prospective candidates by introducing an examination to test their knowledge of accounts, but when Catherwood was interviewed by the accountant at the medical board office, the latter apparently "satisfied himself touching my skill at arithmetic by demanding if the quartern loaf of $5 \mathrm{lb} 8 \frac{1}{2} \mathrm{oz}$. cost $11 d$., what will $100 \mathrm{lb}$ of bread cost?' with one or two of the same nature."'94 And when Catherwood declared that he would have preferred a job in the commissariat, the opportunity of peculation was held out to him as an inducement to join-"when on service, he might save all his pay". ${ }^{95}$

McGrigor, indeed, felt that the low pay of the deputy-purveyors and their clerks held out a very natural temptation "to remunerate themselves out of what passes through their hands." ${ }^{96}$ But if some degree of corruption was inevitable, he was also convinced that it could and should be limited by the vigilance of the senior purveyors.

${ }^{90}$ Denis Gray, Spencer Perceval, the evangelical Prime Minister, Manchester University Press, 1965 , p. 325.

'1 S. G. P. Ward, Wellington's headquarters, London, Oxford University Press, 1957, p. 72.

'2 Wellington's Dispatches, VII, p. 50, W. to Gordon, Cartaxo, 19 December 1810.

22 Gray, op. cit., note 90 above, p. 327.

"Catherwood, op. cit., note 1 above, p. 3.

os Ibid.

of McGrigor, op. cit., note 53 above, p. 361. 


\section{Kate Crowe}

The crimes of Gunson and Dickson were thus doubly serious, for besides defrauding the public on a scale far exceeding that of their subordinates, they were responsible for having fostered a climate of opinion in which embezzling was so much the norm that it was difficult to be honest. Pratt and his friends would never have dared to milk the government so much if McGrigor, rather than Dickson, had been their immediate superior officer. Dickson's conduct is even more unpardonable when seen in a wider context, for he took advantage of the priority given by Wellington to the medical department's demands for money, to line his own pockets when the supply of specie was at its lowest, and the wages of officers and men months in arrear.

Catherwood himself does not seem to have had an attractive personality, and he played only a minor role in the discovery of fraud committed by the purveyors. His 'Narrative', however, is unique-the only memoir to have been written by a member of this important, if little-known sub-department-although in view of the potentially explosive subject-matter, the silence of his colleagues is perhaps quite understandable. Catherwood turns over the stone to reveal the extent of the corruption wriggling beneath, and the truth of his main arguments and many of his details are borne out by such impeccable independent sources as Richard Dawkins. But while the evidence presented by the auditor-general is mostly undigested, Catherwood provides a commentary on a complex situation, bringing it alive by showing how people and isolated incidents fit into the general pattern. It is an important source for those interested in the medical service of the army in this period, but historians of the Peninsular War would also find it both fascinating and useful. This manuscript therefore deserves to be more widely known. ${ }^{97}$

97 I am at present editing Catherwood's 'Narrative' with a view to publication. 